\title{
総合制御所における電力系統運用支援 エキスパートシステムの開発
}

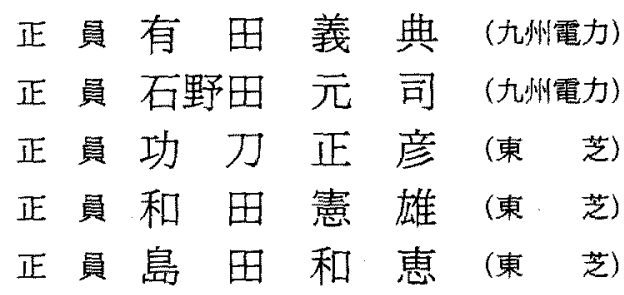

\section{Development of an Operation Supporting Expert System for Power Networks in an Integrated Control Center}

Yoshinori Arita, Member, Motoji Ishinoda, Member (Kyushu Electric Power. Co., Inc.), Masahiko Kunugi, Member, Norio Wada, Member, Kazue Shimada, Member (Toshiba Corp.)

To realize an operation supporting expert system for large-scale power networks, two items are considered to be especially important. The first is inference speed and the other is an interface between an expert system and a conventional energy management system (EMS) or a SCADA system.

To improve inference speed a dedicated artificial intelligence processor and a specific domain shell for real-time expert systems are adopted, and also reduction of rule-search space size is devised considering features of power networks. Tightly coupled interface and distributed database between a logic-program-based system and a procedural-program-beased system are desirable.

An operation supporting system for a large-scale power network has been developed and installed in Fukuoka Integrated Control Center, Kyushu Electric Power Company. The system is configured of triple super-minicomputers with back-ended artificial intelligence processors, and also of dual micro-processor-based front-end-processors (FEPs). Knowledge-based functions, such as fault determination, restoration procedure generation, security monitoring and operation planning are installed in addition to conventional functions of an EMS and a SCADA system. The inference results and their inference speed are satisfactory.

キーワート：電力系統，運用支援，エキスパートシステム

\section{1. まえがき}

良質な電力の安定供給は, 近代的社会生活を維持す るためのインフラストラクチャであり，高度情報化社 会への進展はその重要性をますます高めている。電力 系統の大規模化・高密度化は, 系統運用の自由度を高 めたが，一方では最適な運用を行うための負担を運用 者に強いることとなり, 電力系統運用自動化システ
ム・電力系統運用支援システムの必要性を高めている。 系統運用方法は，経験的な知識に基づく部分も多 く、特に系統事故時の対応業務についてはそうであ る。従って系統運用へのエキスパートシステムの適用 が比較的早くから検討され，研究開発の成果も数多く 報告されている[例元识，文献(1)(2)]。しかし，こ れらの多くは，(i)小規模のモデル系統により実現性 の検証を行っている，(ii)大規模系統を対象としてい 
てもプロトタイプシステムであり，系統運用にあたつ て最も重要な特性である応答性能が必ずしも满足でき る值ではない，(iii)既設の自動給電システム(EMS) や発変電所集中制御システムに付加したシステム構成 をとって扔り，従来システムとエキスパートシステム と注互いに独立性の高い粗結合をしており，リアルタ イム処理システムにおける手続き形プログラムと論理 形プログラムとのインタフェースとして必ずしも望ま しい形態でない,などの課題を含んでいる。

このたび，著者らは，これらの課題に対処した大規 模系統運用支援システムを開発した。その特徵は，次 のと㕲りてある。

(1)従来システムとの密結合形インタフェース方式 従来の自動給電システム・発変電所集中制御システ 么に代表される，手続き形言語を用いて構成されてい る従来システムと、コンピュータ内部バスにより密結 合している。

（2）リアルタイム処理性能の向上系統運用支 援エキスパートシステムを大規模系統に適用する際に 最も重要な特性の一つであるリアルタイム処理性能を 向上するために，下記手法をとった。

(i) AI 処理専用プロセッサの採用

(ii）りアルタイムエキスパートシステム構築ツー ルの採用

（iii）電力系統の特性を考慮した探索空間の制限

以下の章で，従来システムとのインタフェース方式 およびりアルタイム処理性能向上手法についての害現 方式を述へ，更に，大規模系統を対象とする系統運用 支援システムの実現例として，九州電力福岡支店総合 制御所用に開発したシステムについて，構成・機能・ 性能などを述べる。

\section{2. 従来システムとのインタフェース方式}

従来のEMSなどとのインタフェースの方式として
は，（1）一体形，（2）密結合形，（3）の別置形が考总 られる(図 1 参照)。

(1) 一体形 オンラインの処理コンピュータ上 にAI 処理が同居する形態である。

（2）密結合形 オンライン処理コンピュータに 内部バスによる密結合の AI 専用プロセッサを密結合 する形態である。

（3）別置形 オンライン処理コンピュータに踈 給合のエキスパートシステムコンピュータ(例：エン ジニアリングワークステーション)を設ける形態で ある。

以上述べたように三種類の方式があるが，今回開発 したシステムは以下の理由により密結合形を採用 した。

〈2・1〉密結合形を採用した理由 系統事故時の 刘応を主とする系統運用支援システムは，従来の EMS の機能である系統の監視・制御・運用計画などと 密接な関係がある。それ充，密結合であることが望 ましい。また事故時の対応を考元ると特に高速処理性 が必要となる。ところが, 事故時は EMSのコンピュ 一タの負荷も高くなるので，エキスパートシステム用 のコンピュータは EMSのコンピュータとは独立して 動くことが望ましい。

以上のことから，本システムではエキスパートシス テム専用のバックエンドプロセッサ(AIP)を搭載した システムを採用した。AIPは，参考文献(4)にある ように，RISCアーキテクチャにLISP・PROLOG 専 用命令のファームウェア化, データタグ処理用ハード ウェアの追加などの拡張を行い, AI 用言語(LISP, RPOLOG)を高速に妈理するコンピュータである。

〈2・2〉 AIP とオンラインシステムコンピュータ (ホスト)との機能分担 ホストコンピュータでは, 監視・制御・運用計画が必要とする電力系統のデータ (設備つ充停電状態, 接続状態など)をリアルタイムに

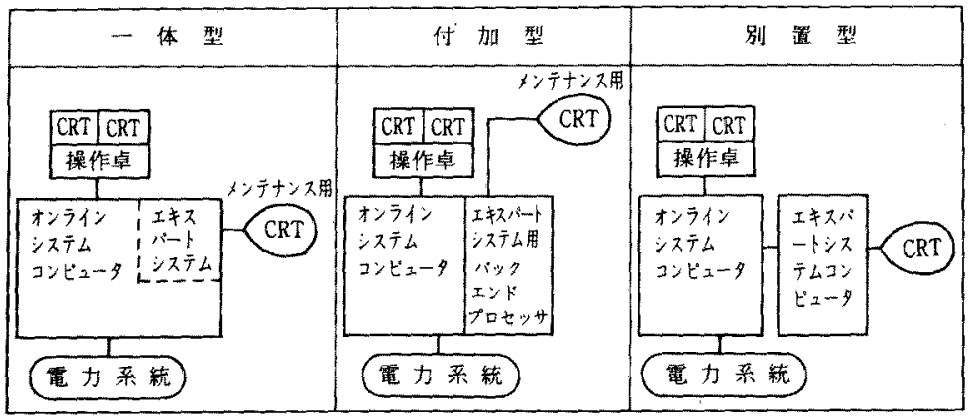

図 1 従来システムとのインタフェース方式

Fig. 1. Expert system interfaced with EMS/SCADA system. 


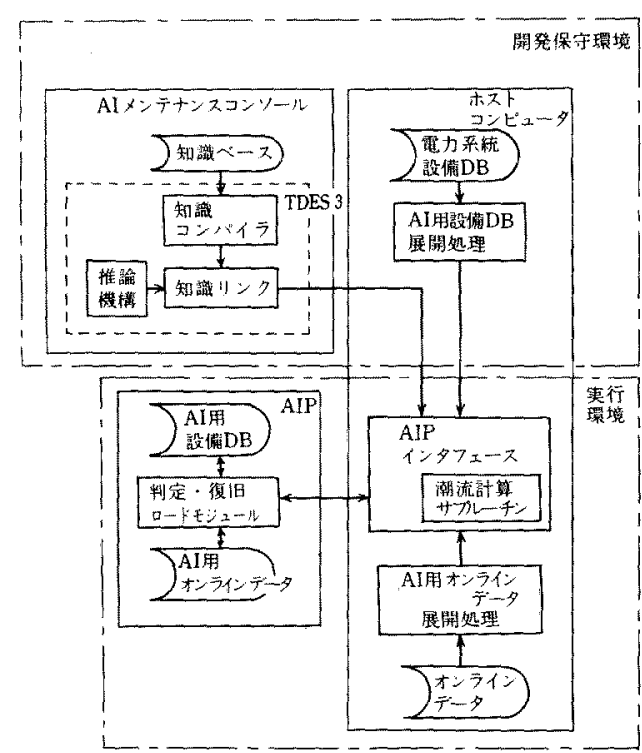

図 2 AIPを組込んだシステムのソフト ウェア構成

Fig. 2. Software configuration of the sys. tem with AIP.

作成している。AIP上に実現している專故判定・復旧 手買作成の土キスパートシステムはこれらの電力系統 のデータを朋いている。AIPとホストコンピュータ に打けるデータのもちかた，機能分担について図 2 を 用いて説明する。AI 処理に必要な固定データ(例：設 備定数，保護りレーの整定值など）を得るためのAI 用設備データベース (DB) 屡開処理は，システムで一 括管理している電力系統設備 DBから必要なデータを 抽出して事故判定・復旧の処理しやすい形に亚び替え 編集しておく。これはシステムメンテナンス時にバッ クグラウンドの処理で実行しディスクメもリーに保存 しておく。ホストコンピュータでオンライン処理が実 行されるとき判定・復旧のロードモジュールとAI用 設備 DBはAIPインタフェース処理を介してAIPに ダウンロードされる。事故判定・復旧の要求があった ときには，AI用オンラインデー夕罣開処理はオンラ インデータのなかで事故判定・復旧に必要なデータの みを抽出し，AI用オンラインデータとして編集する。 編集したデータはAIPインタフェース処理がAIPに 転送し推論を起動する。このようにAIPで專故判定， 復旧の推論処理を行うために必要なデー夕をホストコ ンピュータで作成し AIP 上に転送することによって, AIP とホストコンピュータとは並列処理を行うこと か可能となる。

ところで事故復旧の推論過程では潮流計算が必要に
なる。手続き形言語(C, FORTRAN)で記述されて いる潮流棓算好理は，ホストコンピュータ上ても AIP 上でも実行可能である。ホストコンピュータに よる場合，その計算時間は AIPとホストコンピュー 夕間のデー夕転送時間を考慮してもAIPによる場合 とほ隹同じであることと，ホストコンピュータでの EMS 機能が必要不可久な機能として潮流計算ルー子 ンが準備されていることから，ホストコンピュータ上 で実行することにした。潮流計算は，図 2 に示すよう にAIPインタフェース処理からサブルーチンの形式 でコールされる。

復旧手順作成の推論実行時に潮流計算が必要になっ た場合は, AIP 側から系統変更データをホストコン ピュータ上のAIPインタフェース処理に転送する。 AIPインタフェース処理は転送された系統変更デー 夕に従って潮流計算用の系統情報を書き換光潮流計算 を要求する。潮流計算の結果は AIPインタフェース から AIPに転送される。DB，オンうインデータ，潮 流結果などのデー夕を転送する際に以下の 2 点に留意 した。

（1）転送サイズの縮小転送時間は転送サイズ に比例して大きくなる。オンラインデータを編集せず に一括して転送する方法と必要なものを取出して編集 して転送する方法がある。本システムではオンライン データの編集時間は短いので必要なものを取出して編 集して転送する方法を採用した。

(2) LISP 型データへの変換 オンラインシス テムコンピュータでの電力系较のデータベースはC 空語の配列データで, その型はビット型, 整数型, 浮 動小数点型が混在した構造体となっている。AIP上 ではCとLISP は両方共実行可能であるからC 罟語 の配列データのままでもアクセス可能だが, LISPO 推論機楧で柔軟に扱えるようにデータベースをLISP のリストに変换している。変換方法は以下のとおりで ある。

(i) 全データを整数型の配列にする。

(ii) LISPのデータの型夕グを付ける。

(iii）整数型の配列データをLISP のりストに変換 する。

全データを整数形にするのはLISP で扱う際の姏理 を簡絜にするためである。

\section{3. リアルタイム処理性能向上手法}

リアルタイム処理性能向上施策として以下の3点に ついて述べる。

（1） AIPの採用 AIPの機能については，前 
章で述バた。

AIP 適用することにより，エキスパートシステ 厶0性能は 6 ～倍向上する。しかも，事故時におけ るホストコンピュータでの電力系統のアラーム処理に は全く影響を与えずに実行できる。本システムの場 合, 10 分間に 1200 状変発生という大規模系統事故の ときに一体形と比較して 10 分間平均のホストコンピ ュータの負荷注, 状変発生箇所によって異なるが $20 \sim 40 \%$ 減少した。

（2）コンパクトな奏行環境を提供するリアルタイ ムエキスパートシステム構築ツールの採用電力系 統としては，「電源をさがす」電源からの経路をさが す」のような手続き処理が知識処理の条件部，実行部 に表れる。このように手続き処理を呼び出せることが ツールとして必要不可欠である。本システムではリア ルタイムエキスパートシステム構築ツール TDES 3 上に構築した。TDES 3 については文献 $(4)$ に説明 されているが，以下の機能をもつ。

(i) 知識表現としてファクト, スキーマ, プロダ クションルール,ルールモジュール，手続きがある。

(ii) 前向き推論, 後ろ向き推論の両方の推論機能 をもつ。

スキーマのデモン,プロダクションルールの条件 部, 実行部からの手続きの呼び出しを用いた推論が可 能である。リアルタイムエキスパートシステム構築ツ 一ルとして実行時における高速性, コンパクト性を実 現するために開発環境と実行環境を分墔している。 TDES 30 開発環境を用いて作成した知識バースは, 図 2 AI メンテナンスコンソールで, まず知識ベー スコンパイラによって実行可能なブログラムに変換さ れる。更に知識りンカによって推論機構, 外部インタ フェースおよびューザ定義外部関数と一体となって単 独で実行可能な判定復旧ロード・モジュール人と変換 される。このようにしてエキスパートシステムがシェ ルから分離され独立したタスク，プロセスとして実行 できるために高速でかつコンパクトな実行環境を実現 することができる。汎用のツールと比較して一けた程 度処理速度が速い。

（3）推論の探索空間の制限 TDES 3 は(2) で説明したように高速なシェルではあるが, 事故判 定・復旧の処理でも以下のようにして推論の探索空間 の制限を行って推論時間を短縮している。

(i) 事故判定に必要な系統の切出し 事故で停 電した設備で実際に事故にあったと考えられるのは, 保護りレーの整定と保護りレーの誤不動作の可能性を 考えると保護りレ一の動作した遮断器から送電線区間
にして高々 3 区間までである。ホストコンピュータ上 でオンシインデータを編集する際に，トリップした遮 断器加ら負荷㑡設備については3区間を切出して編集 しAIPに転送する。このような系統切出し処理を行 うことによって AIP 上での事故判定推論の探索空間 は減少し，必た転送サイズも縮小し処理速度が句上 する。

(ii) ルールのモジュール化 TDES 3 の機能 の一つにルールモジュールがある。事故復旧の知識は 復逃理の流れに従って全部で13のルールモジュー ルに分割されており，復旧の推諭の途中経過で必要な ルールモジュールのみを活性化することによって探索 空間の減少，ひいては処理速度の向上を図っている。

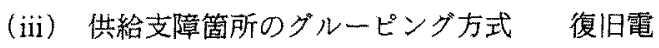
源中復旧ルートを供給支障简所一つ一つについて検討 するとその組合せ数が膨大になり，推論時間も長くな る。本システムでは, 効率艮く復旧電源や復旧ルート を見つけるために供給支障筍所のグルーピング方法を 採用している。詳細はく4・5 節〉比心゙る。

\section{4. 運用支援エキスパートシステム}

本章では，前述の検討結果に基づいて開発した大規 模系統を対象とする運用支援エキスパートシステムに ついて述心る。

〈4・1〉対象系統 本シスデム房, $66 \mathrm{kV}$ 系統を 主体に $220 \mathrm{kV}$ 系統， $110 \mathrm{kV}$ 系統加らなる都市部の 系統を対象としており，系統を構成する電気所数は， 当初 45 箈所，将来 100 筒所程度である。

本システムで取扱う情報量は, 遮断器・盺路器の 入入切状態, 保護りレーの動作，切換えスイッチの状 態などのステイタス情報：約 18,000 点, 送電線の有 効 - 無効電力, 母線電圧, 変压器の有効. 無効電力, タップ值などのテレメータ情報：約 2,500 量と膨大で ある。

〈4・2〉 ハードウェアシステム構成 本システム のハードウェア構成を図 3 に示す。ホストコンピュー タには，スーパーミニコンピュータTOSBAC G8050が 3 台使用されて扔り，常時，2台は監視制 御用として 2 重系オンライン運転を行い, 残り 1 台は 運用計画やメンテナンス用としてオフライン運転を行 つている。各コンピュータには, AIPが各 1 台付加

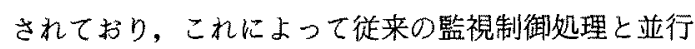
して AI 処理を高速に実行することができる。

マン・マシンインタフェースの中心にはグラフィッ ク CRT 2台を組込九た操作卓が設けられており, 監 視制御情報や $\mathrm{AI}$ 処理結果が提示される。またエキス 


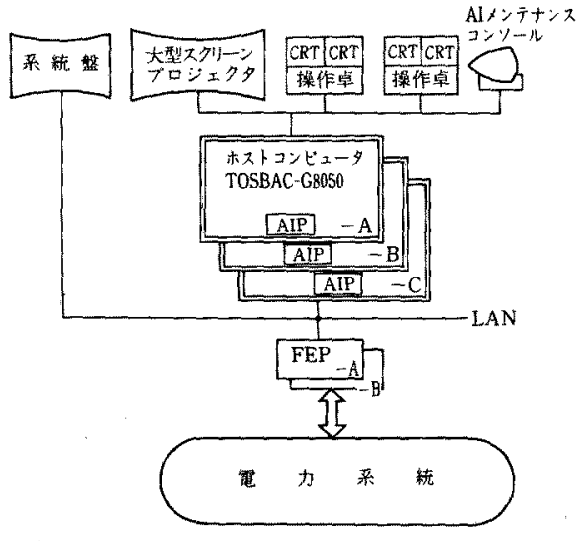

図 3 ハードウェアシステム構成

Fig. 3. Hardware configuration.

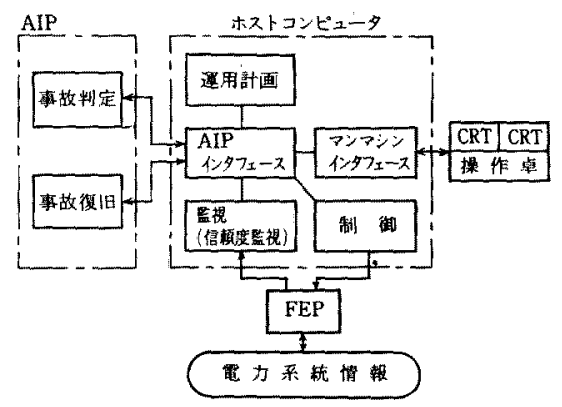

図 4 エキスパートシステム

Fig. 4. Functions of expert system.

パートシステム開発・保守用に AI メンテナンスコン ソールが設けられている。

前述の電力系統のステイタス情報やテレメータ情報 は，フロントエンドプロセッサ(FEP)で状態変化検 出処理やスケール変換処理が行われた後，ホストコン ピュータ人取込まれる。

〈4・3〉工キスパートシステム機能構成 本シス テムの機能構成は図 4 亿示す通りで，ホストコンピュ 一タ上で実行するプログラムと AIP 上で実行するプ ログラムからなっている。ホストコンピュータでは, 系統の監視・制御，運用計画などの機能や CRT との インタフェース処理, AIP とのインタフェース処理 が手続形言語(C, FORTRAN)で記述され，従来形 のソフトウェアとして実現されている。一方, AIP で，事故判定機能・事故復旧機能がリアルタイムエ キスパートシステム構筑ツール TDES $3 て ゙$ 記述され, コンパイルされた後LISPプロク゚ラムとして実行さ れる。

ホストコンピュータ上のプログラムと AIP 上のプ

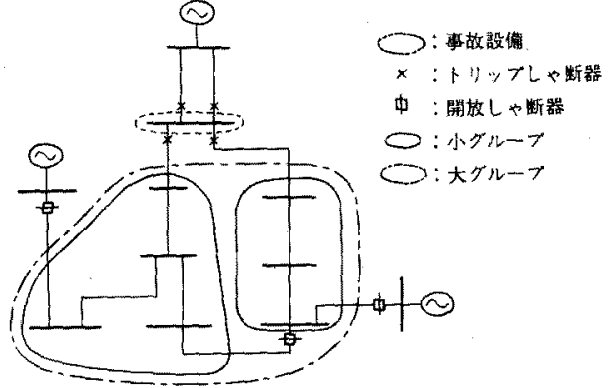

図 5 供給支障䉒所のグルーピングの例

Fig. 5. An example of grouping of power outage area.

ログラムは並列動作を行うが，AIP 上のプログラム の起動はホストコンピュータからの指令により行われ る。例えば，系統事故が発生し，ホストコンピュータ の監視機能が事故発生を確認すると, AIPインタフ エースが AIP 上の事故判定ブログラムに起動をか外， AIP 上で事故判定処理が実行され，その結果は AIP インタフェースヘ渡され，マン・マシンインタフェー スを通してCRT 上へ表示される。

〈4.4〉事故判定システム 基本的には既発表諭 文(1)(3)のと坊りであるが，今回大規模系統を対象とし ている点から多重事故を最大 6 䇢所まで考慮して いる。

〈4.5〉事故復旧システム＼cjkstart本復旧システムは， （i）事故設備の切離し，（ii）過負荷解消，（iii）供給 支障解消，(iv)復旧残対策の四つの機能で構成されて いる。特に過負荷解消と供給支障解消の実現手法とし て，事故前からもともともっていた健全系統の負荷の 一部を他の系統へ切換えるという多段切換方式を採用 している。また，今回のような大規模系統では，広範 囲にわたる供給支障が発生した場合，復汨に用いるこ とのできる電源は複数個存在し，どの電源を用いてど の負荷まで供給すべきかを決定するためのルート探索 空間が大きい。本復旧システムでは，この問題を解決 するため以下に示す供給支障箇所のグルーピング方式 を導入している。

図 5 に示すように，供給支障简所の中で事故直後操 作完了後に系統上接続されている系統設備の集合を小 グループと呼び，現状接続されていないが，開閉器を 投入することにより接続可能な系統設備の集合を大グ ループと呼ぶ。大グループ単位に供給可能な電源を確 保し，小グループ単位に供給支障解消の操作を行うこ とにより，操作回数が少なく，かつ供紷支障籄所を小 さくする復旧操作が可能となる。

本復旧システムでは，事故復旧時に運転員の操作を 


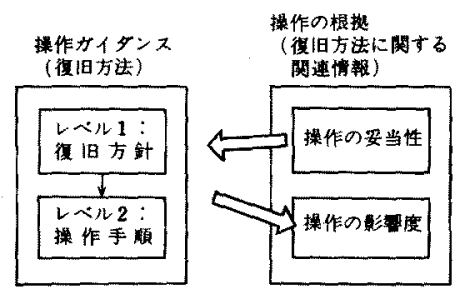

図 6 事故復旧支援におけるマン・マシン インタフェース

Fig. 6. Man machine interface for fault restoration guidance.

0361 復旧手順結果

89 年7月21日鉜19時36分 次画面あり 復旧手順 住吉 $66 \mathrm{kV} \# 2$ 線事故 89 年 7月21日19時26分12秒開始

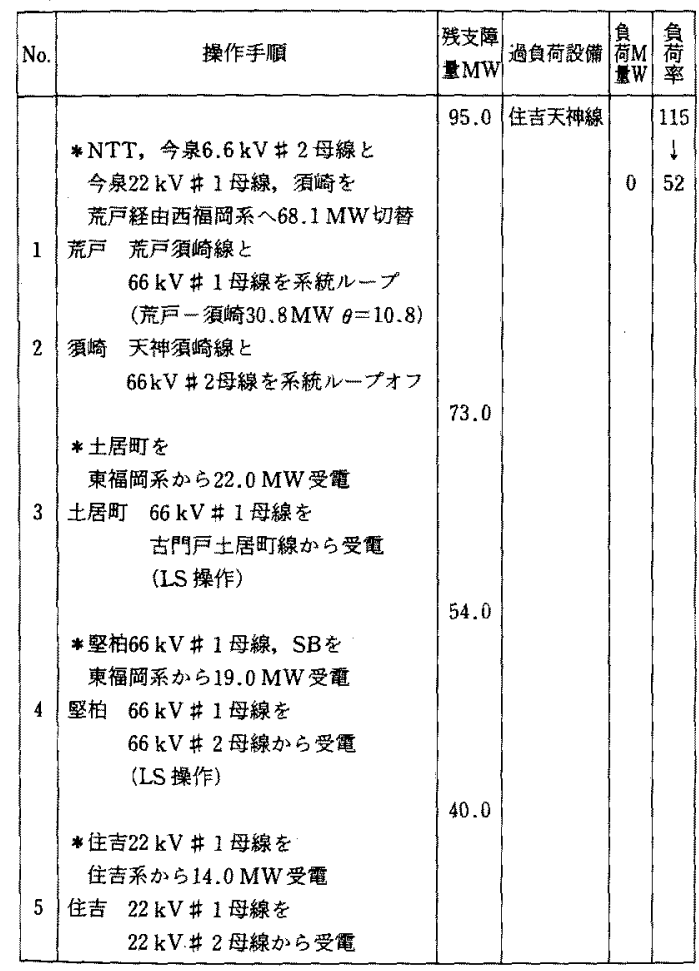

(注)*印は復旧方針，No.1〜 5 㹥操作手䐓である。

\section{図 7 復旧手順結果の表示例}

Fig. 7. Display example of restoration procedures.

支援するため，図6に示すように復旧方針と操作手順 の二つのレベルに階䁲化された操作ガイダンスとその 操作の根拋 (操作の妥当性・影響度)が合せて提示され る。㩧作がイダンスの内容を以下に示す，

（1）復旧方針メッセージ メッセージごとに， (i) 当該操作手順実施時の供給支障量, (ii) 当該操作 手順実施時, 最も過負荷率の高い設備および当該設備

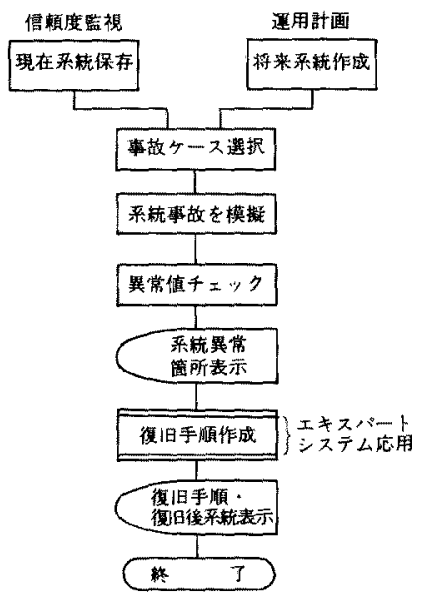

図 8. 信頼度監視, 運用計画への エキスパートシステムの応用

Fig. 8. Expert system application to security analysis and operation planning.

の過負荷量と過負荷率の操作前後の変化が提示さ れる。

（2）操作手順メッセージ 操作手順ごとにルー プ切換時の相差角とループ潮流の值と方向が提示さ れる。

これらのメッセージで構成された復旧手順の出力例 を図 7 に示す。

$\langle 4 \cdot 6\rangle$ 信頼度監視への応用平常時の系統信頼 度監視において想定事故後の復旧手順作成にエキスパ 一トシステムを適用している。その処理フローを眓 8 に示す。これによって，復旧手順と復旧後系統を考慮 した上で系統の信頼度を把暒できるので，事前に系統 切換えなどの対策を講じることができ，また事故発生 時に行うべき復旧操作を事前に检討しておくこともて きる。

〈4・7〉運用計画人の応用図 8 に示寸とおり, 将来系統に対し，前節と同様にエキスパートシステム を適用している。これによって夏期ピークや軽負荷期 などに掩ける系統運用計画をよりきめ細かく立案する ことができる。

〈4・8〉 処理性能 事故の種別ちよび多重性によ $\eta$, 推論処理時算は変る。事故判定処理には，20～30 秒, 復旧手順作成処理には 60 150 秒の応答性能が得 られた。

\section{5.あとがき}

本システムは，工場における製作・総合試験を完了 し，現在フィールドに括ける試験中であり，期待どお 
りの出力結果が得られている。処理時間についても, ほ満满できる性能となっている。今後は, フィール ドでの運用実績を踏まえて, 知識の一層の充実を図っ ていく計画である。

本システムの開発にあたり，指導・助言・協力をい ただいた九州電力および東芝の関係各位に深謝いたし ます。

(平成元年 9 月 25 日受付, 同 2 年 2 月 21 日再受付)

\section{文献}

(1) S. Moriguchi, et al : "An Expert System for Power System Fault Analysis and Restoration", Proc. of CIGRE. SC 39, p. 23-I(1987)

(2) D. S Kirschen, et al. : "Artificial Intelligence Applications in an Energy Management System Environment", Proc. of Symposium on Expert Systems Application to Power Systems, p. 17-1 (1988)

(3) N. Koike, et al. : "A Real-Time Expert System for Power System Fault Analysis", Proc. of IASTED Int. Symposium, p. 376(1986)

（4）川北，他：「リアルタイムエキスパートシステム用統合 $\mathrm{AI}$ 璵境」, 電学論 $C, 109,101$ (平元-9)

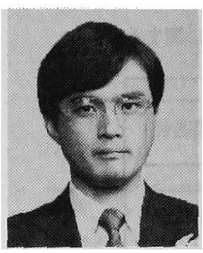

石野田 元 司(正貝)

昭和 56 年宮崎大学工学部電気工 学科卒業。同年九州電力 (株) 入社。 現在，工務部総合制御開発班にて電 力設備総合自動化開発業務に従事。

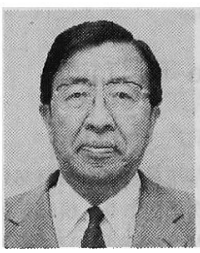

\section{功 刀 正 彦 (正員)}

昭和 33 年 3 月東京大学工学部電 気工学科卒業。同年 4 月(株) 東芝入 社。府中工場勤務。主として, 電力 用計算機システム開発に従事。人工 知能学会, IEEE 各会員。

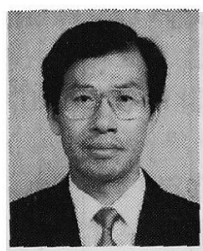

和田憲雄（正員）

昭和 48 年同志社大学工学部電気 工学科卒業。同年 (株) 東芝入社。現 在同社電力系統技術部涪勤。電力 系統制御システムおよび AI 応用シ ステムの開発に従事。

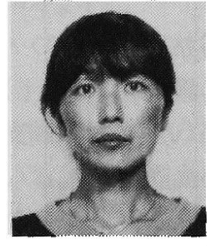

従事。

\section{島田和恵（正員）}

昭和 55 年扔茶の水女子大学大学 院理学研究科修士課程終了。同年 4 月 (株) 東芝入社。府中工場勤務。主 として電力用計算機システム開発に 在, 工務部総合制御開発班課長。電 力設備総合自動化開発業務に從事。
昭和 42 年九州工業大学制御工学 科卒業。同年九州電力 (株) 入社。現 